\title{
MORPHOLOGY AND ANATOMY OF LEAF MINE IN Richterago riparia ROQUE (ASTERACEAE) IN THE CAMPOS RUPESTRES OF SERRA DO CIPÓ, BRAZIL
}

\author{
MELO DE PINNA, G. F. A., ${ }^{1}$ KRAUS, J. E. ${ }^{2}$ and MENEZES, N. L. de ${ }^{2}$ \\ ${ }^{1}$ Departamento de Botânica, Centro de Ciências Biológicas, Universidade Federal de Pernambuco, CEP 50372-970, \\ Recife, PE, Brazil \\ ${ }^{2}$ Departamento de Botânica, Instituto de Biociências, Universidade de São Paulo, CEP 05422-970, \\ São Paulo, SP, Brazil \\ Correspondence to: Gladys Flávia de A. Melo de Pinna, Departamento de Botânica, Centro de Ciências Biológicas, \\ Universidade Federal de Pernambuco, Av. Prof. Moraes Rego, s/n, Cidade Universitária, CEP 50372-970, \\ Recife, PE, Brazil, e-mail: gfmelo@npd.ufpe.br \\ Received May 22, 2000 - Accepted November 28, 2000 - Distributed February 28, 2002
}

(With 15 figures)

\begin{abstract}
The leaf mine in Richterago riparia is caused by a lepidopteran larva (lepidopteronome). The leaves of $R$. riparia show campdodrome venation; the epidermis is unistratified, with stomata and glandular trichomes in adaxial and abaxial surfaces. The mesophyll is bilateral and the vascular system is collateral. During the formation of the mine, the larva consumes the chlorenchyma of the mesophyll and the smaller vascular bundles (veins of third and fourth orders). Structural alterations in the tissues of the host plant were not observed, except for the formation of a wound meristem and the presence of cells with phenolic substances next to the mine. Three cephalic exuviae of the miner were found in the mesophyll. This lepidopteronome is parenchymatic and the epidermis remains intact, but forms a protective layer for the mining insect.
\end{abstract}

Key words: leaf mine, lepidopteronome, anatomy, morphology, Richterago, Asteraceae.

\section{RESUMO}

\section{Morfologia e anatomia de mina foliar em Richterago riparia Roque (Asteraceae) nos campos rupestres da Serra do Cipó, Brasil}

A mina foliar de Richterago riparia é causada por uma larva de lepidóptera (lepidopteronoma). As folhas de $R$. riparia apresentam venação campdódroma; a epiderme é uniestratificada, com estômatos e tricomas glandulares nas superfícies adaxial e abaxial. O mesófilo é bilateral e o sistema vascular, colateral. A larva, durante a formação da mina, consome o clorênquima do mesófilo, bem como os tecidos vasculares de menor porte, por exemplo, as nervuras de terceira e quarta ordem. Não ocorreram alterações estruturais em relação ao tecido da planta hospedeira, exceto a formação do meristema de cicatrização e o aumento do teor de substâncias fenólicas nas células da mina. Constatou-se, ainda, a presença de três exúvias cefálicas do minador no mesófilo. Essa mina é do tipo parenquimática, na qual e a epiderme permanece intacta, protegendo o inseto minador do meio externo.

Palavras-chave: mina foliar, lepidopteronoma, anatomia, morfologia, Richterago, Asteraceae.

\section{INTRODUCTION}

Mines or hyponomes are channels caused by insect larva inside plant tissues. The mine provides both living and feeding quarters for the larva miners (Hering, 1951). Their food is the thin stratum of plant tissue that lies outspread in a seam between any two adjacent strata, and the insects get to it 
and dig it out for use (Needham et al., 1928). Normally, the mine cavity is extended inside the parenchyma of the leaf but may be established inside the parenchyma of other plant organs such as flowers, fruits, stems, or roots (Hering, 1951).

Mines are caused by insect larvae, which are endophytophagous and thus are internal plant parasites (Weis \& Berenbaum, 1989). According to Needham et al. (1928), miners are among the smallest of plant-eating animals. Only four insect orders can be considered as producers of mines, of which Lepidoptera and Diptera comprise the greatest number of species, while Hymenoptera and Coleoptera have been less frequently identified as having mining insects (Hering, 1951). Approximately 10,000 species of leaf miners were described (Connor \& Taverner, 1997) and the leaf-mining habit had originated at least by early Cretaceous (Labandeira et al., 1994).

Leaf miners in economically important plants such as rice, tomato, asparagus, spinach, coffee, apple, peach, blueberry, blackberries, azalea, chrysanthemum, morning-glory, columbine, among others, have been described by Yepsen (1976) and Hill (1987). Mines are found in a large number of plant families including Dipsacaceae, Solanaceae, Chenopodiaceae, Boraginaceae and Asteraceae (Hering, 1951). Unfortunately, in the Asteraceae family, most of the studies about mines mainly describe the life history and immature stages of the inducer insect (Boldt \& White, 1992; Goeden et al., 1993, 1995), and little attention is given to the histological alterations in plant tissues.

In the neotropical region, especially in Brazil, studies of hyponomes have received relatively little attention, although they are biologically important (Connor \& Taverner, 1997). Insects on Asteraceae provide convenient microsystems for laboratory and field studies on the dynamics and evolution of phytophagous insects and their hosts. Lepidoptera contribute substantially to overall phytophagous richness, but occur less often and in a smaller number than the major Diptera order (Lewinsohn, 1991).

The aim of the present study is to analyze the anatomical alterations caused by a lepidopteran in leaves of Richterago riparia Roque (Asteraceae).

\section{MATERIAL AND METHODS}

Specimens of Richterago riparia Roque were collected in the campos rupestres of Serra do Cipó,
State of Minas Gerais (Brazil): Roque \& Hervêncio 493 (holotype SPF).

Healthy and mined leaves were fixed in FAA (formalin, acetic acid, and 50\% ethanol, 1:1:18, v/v) (Johansen, 1940) for 48 hours. After fixation they were dehydrated in $50 \%$ and $70 \%$ ethanol.

For larvae observation, the leaves were cleared according to Foster (1950, in Kraus \& Arduin, 1997). For anatomical studies, transverse sections were obtained using razor blades. For routine analyzes, the sections were stained with astra blue and basic fuchsin (Kraus et al., 1998). Phenolic substances were detected using 10\% ferric chloride (Johansen, 1940), and for the characterization of lipids Sudan IV was used (Gerlach, 1984, in Kraus \& Arduin, 1997).

\section{RESULTS}

The leaves of Richterago riparia show campdodrome venation and glandular trichomes (Fig. 1). Trichomes were observed on the adaxial and abaxial surfaces of the epidermis. The canal or mine left by the lepidopteran larva has a lighter color, as a consequence of the consumption of the internal plant tissues. In its path, the larva ate away veins of third and fourth orders (Figs. 2-4), leaving feces behind as it moved forward. Three cephalic exuviae were found (Figs. 5-7), indicating that the larva underwent three moultings inside the leaf tissue.

Transverse sections of the non-affected leaf, at the region of the middle vein (Fig. 8), revealed an unistratified epidermis, with roundish or quadrangular cells. The cuticle lines both surfaces of the epidermis and is usually thicker adaxially. The cortical region is composed of lacunar collenchyma below the epidermis, both adaxially and abaxially, with a greater number of layers in the latter. The endodermis surrounds the vascular system, showing some sclerified cells. The vascular tissue is externally bordered by several layers of pericyclic fibers. Phenolic substances are present mainly in the phloem and pericyclic fibers, as well as in some cortical parenchyma cells.

Fig. 9 shows the entrance spot of the larva of the leaf mine, located in the region of the midrib on the adaxial surface. During mine formation, the small larva avoided heavily lignified tissues, consuming and moving through the parenchyma cells towards the abaxial portion of the leaf lamina. 


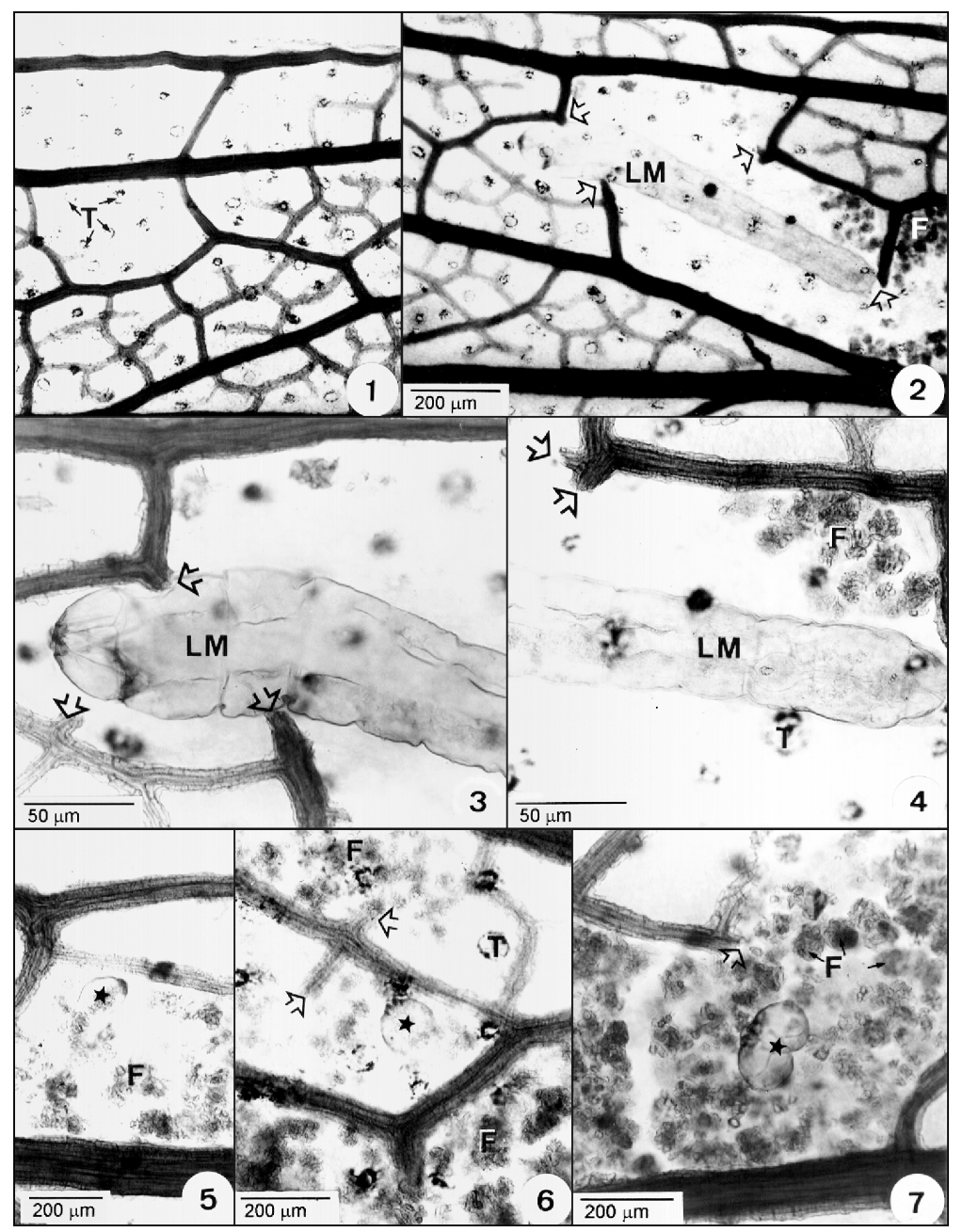

Figs. 1-7 - Leaf of Richterago riparia (Asteraceae). Fig. 1 - Note the camptodrome venation and glandular trichomes in the adaxial epidermis of the non-affected region. Fig. 2 - Observe the lepidopteran larva inside the leaf tissue; note the sectioned veins (arrows) and the feces in the mine. Figs. 3-4 - Anterior and posterior parts of the lepidopteran miner, respectively. Figs. 5-7 - Observe the sectioned veins, the feces and the cephalic exuviae (asterisks) in the mesophyll. F = feces; LM = lepidopteran miner; $\mathrm{T}=$ glandular trichomes.

A transverse section of the mine (Fig. 10) revealed that the larva consumed approximately three layers of mesophyll parenchyma tissue, but left the epidermis and its stomata intact. A wound meristem was formed next to the mine (Fig. 11), with cells displaying some suberized walls and with planes of division mostly periclinal relative to the mine. Those cells, and even the ones located somewhat more externally to the mine, contain a large amount of phenolic substances. The transverse section at the region of lateral veins revealed a unistratified epidermis with stomata (Fig. 12). The mesophyll is bilateral and there is hardly any difference between the palisade and spongy parenchymas. The cells of both parenchymas are slightly lobed, with reduced intercellular spaces, and some of them contain phenolic substances. The larger veins are similar to the midvein in relation to the disposition of vascular tissues; smaller veins have few pericyclic fibers.

Figs. 13 and 14 show the entrance spot of the larva mine in the region of lateral veins. At that stage, the larva consumed only two or three layers of the mesophyll next to the adaxial surface, but part of the epidermical cells and cuticle was left intact. Many cells adjacent to the wound meristem have phenolic substances (Fig. 15). 


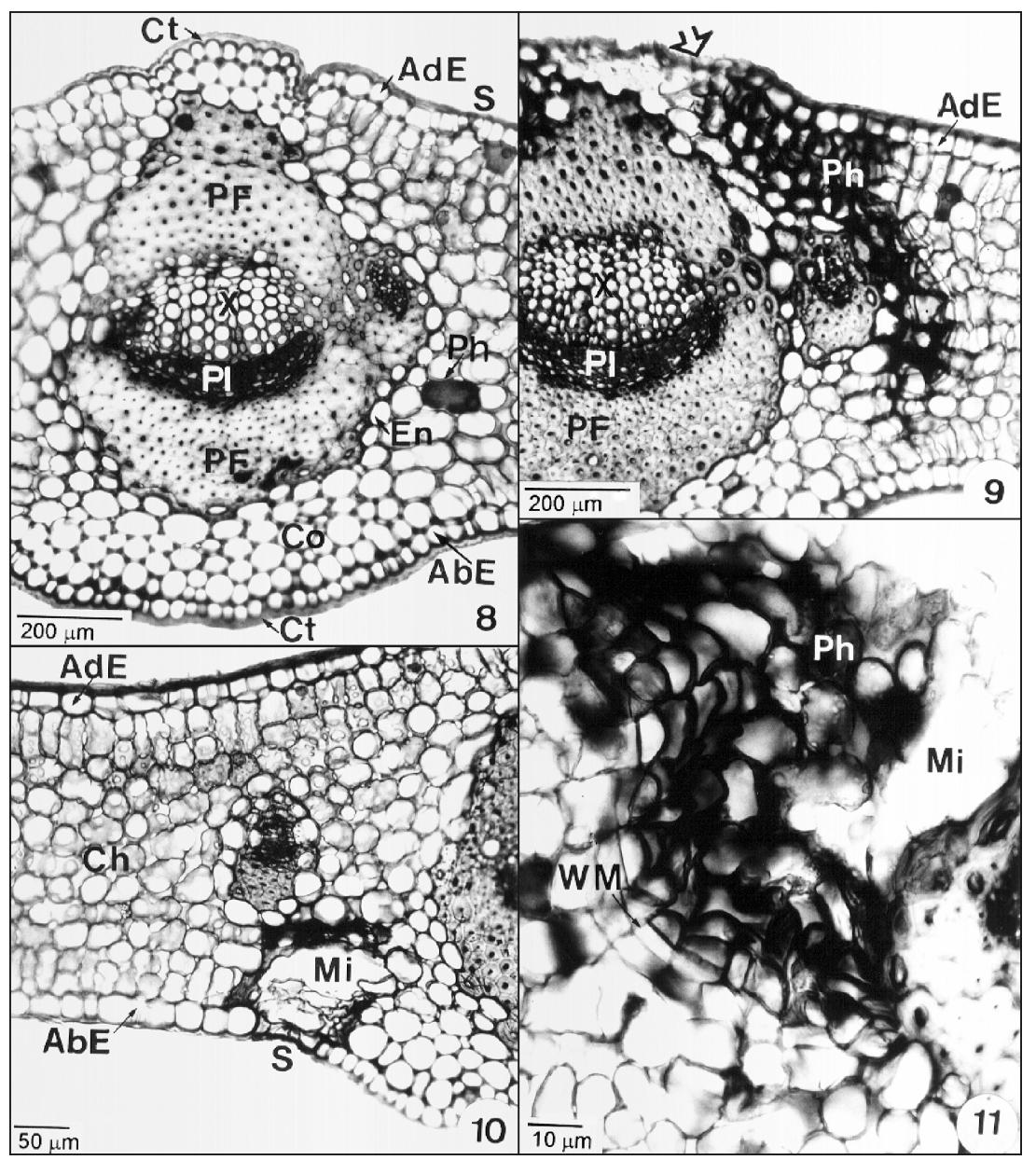

Figs. 8-11 — Leaf of Richterago riparia (Asteraceae): transverse sections. Fig. 8 - Note the dermal system, cortex, and vascular system of the midrib region of the non-affected leaf. Fig. 9 - Observe the entrance spot of the mining larva (arrow) and the cells with phenolic substances near the midrib region. Fig. 10 - The mine left by the lepidopteran larva is located next to the abaxial epidermis; 3-4 layers of the chlorenchyma were consumed by the miner. Fig. 11 - Detail of the mine showing the wound meristem and the cells with phenolic compounds. $\mathrm{Ch}=$ chlorenchyma; $\mathrm{Co}=$ collenchyma; $\mathrm{Ct}=\mathrm{cuticle} ; \mathrm{AbE}=$ abaxial epidermis; $\mathrm{AdE}=$ adaxial epidermis; $\mathrm{En}=$ endodermis; $\mathrm{Mi}=$ mine; $\mathrm{PF}=$ pericyclic fiber $\mathrm{Ph}=$ phenolic substance; $\mathrm{Pl}=$ phloem; $\mathrm{S}=$ stoma; $\mathrm{WM}=$ wound meristem; $\mathrm{X}=$ xylem .

\section{DISCUSSION}

This study was the first one to provide morphological and anatomical information about mines in plants native to Serra do Cipó and the analysis of the affected leaves showed that the miner is a lepidopteran larva that underwent three moultings inside the plant tissues.

According to Hering (1951), lepidopteran larvae are considered as temporary mining insects, feeding inside the mine for a limited period of time. They normally live inside their mines only when young, moving to the outside of the leaf in subsequent stages. According to the same author, young larvae are protected against external aggression and make more efficient use of available food resources, targeting the mesophyll, which is the most nutritious and tender portion of the leaf.

Therefore, when the larva reaches a certain stage of development, the ingestion of nutritious food is not as important as it is in its early stages, and its mouth parts are stronger and better fit to process harder food (Hering, 1951). 


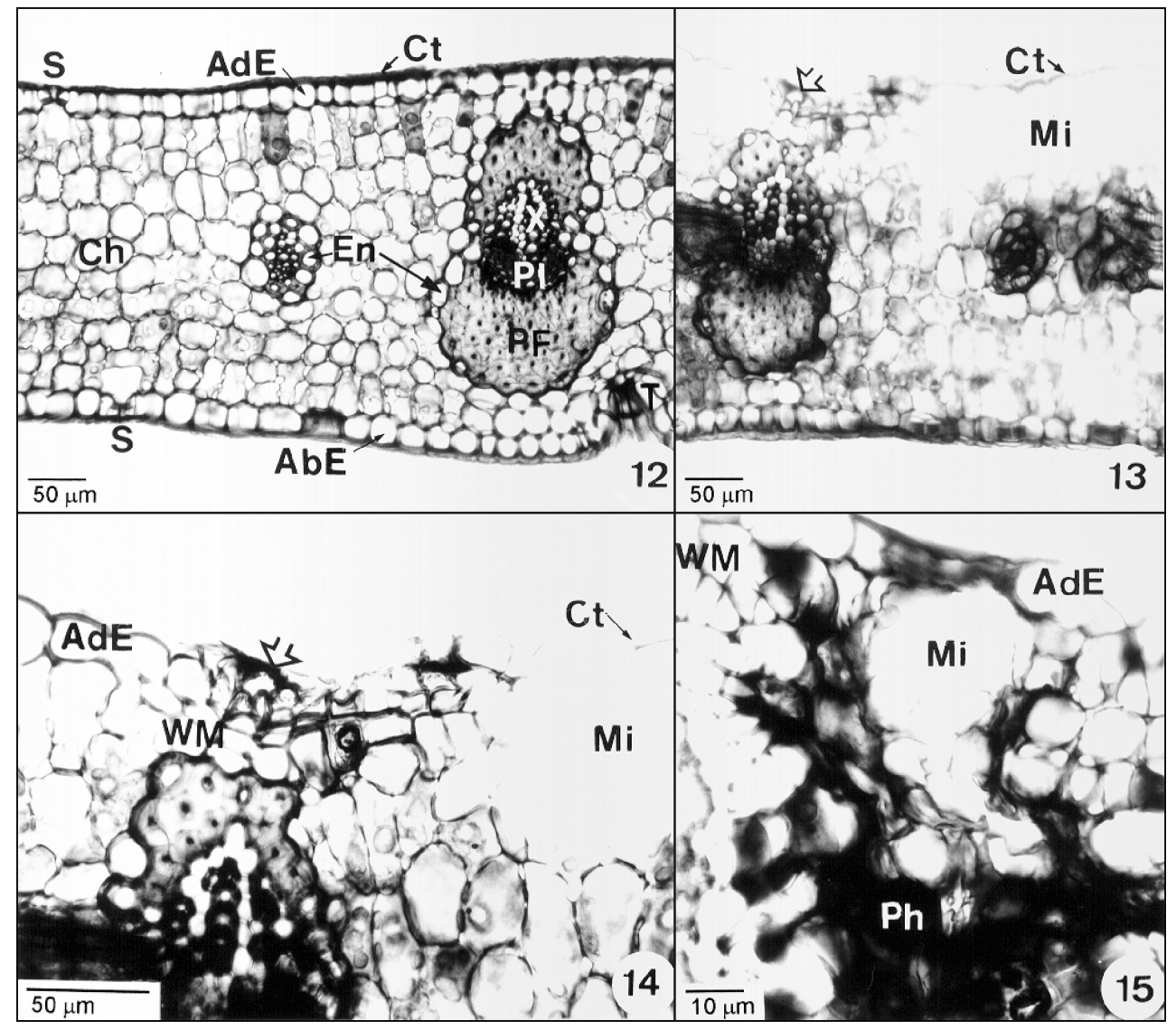

Figs. 12-15 - Leaf of Richterago riparia (Asteraceae): transverse sections. Fig. 12 - Note the dermal system, the bilateral mesophyll and the vascular system in the region of the lateral veins of the non-affected leaf; stomata and trichomes (basal portion) are present. Fig. 13 - Observe the entrance spot of the mining larva (arrow); the mine is situated in the mesophyll and is lined by the cuticle. Fig. 14 - Detail of the entrance spot and the wound meristem. Fig. 15 - Detail of the mine showing cell with phenolic substances. $\mathrm{Ch}=$ chlorenchyma; $\mathrm{Ct}=$ cuticle; $\mathrm{AbE}=$ abaxial epidermis; $\mathrm{AdE}=$ adaxial epidermis; $\mathrm{En}=$ endodermis; $\mathrm{Mi}=$ mine; $\mathrm{PF}=$ pericyclic fiber; $\mathrm{Ph}=$ phenolic substance; $\mathrm{Pl}=$ phloem $; \mathrm{S}=$ stoma; $\mathrm{WM}=$ wound meristem; $\mathrm{X}=$ xylem.

The present study confirms the observations made by Hering (1951), and further shows that the larva consumes the parenchyma tissues of the mesophyll, as well as small vascular tissues.

The mines of $R$. riparia show no preference for specific locations of parenchyma tissues, which are equally targeted, in both the adaxial and abaxial surfaces. Another important point is that there were practically no structural alterations in the tissues of the host plant, but only the formation of a wound meristem around the regions destroyed by the larva. Wound tissue is commonly formed in regions of wounds (Lipetz, 1970) and has a general protective role (Cutter, 1978), regardless of the cause of the wound which can be of an abiotic or biotic nature. The latter is well illustrated by the miner of $R$. riparia. Based on histochemical analysis, the vascular system of the leaves, especially the phloem, proved to be the richest region in terms of phenolic substances. The chemical-barrier adaptive mechanisms near vascular bundles, as discussed by McKey (1979), are correlated with the fact that they are rich in nutrients, particularly the phloem, and are thus strongly targeted by many organisms. On the other hand, there is an increase in the amount of phenolic substances in the cells that either border the mine or are located in its neighborhood. 
According to Feeny $(1970,1976)$, Swain (1979), and Tempel (1981), one of the functions of phenolic substances, notably tannins, is to defend the plant against herbivory, because those compounds precipitate the animals' digestive enzymes, and are thus detrimental to their digestion. Additionally, it cannot be ruled out that phenolic compounds are also present as defense agents against attack by microorganisms, which can otherwise infect lesions caused by the activities of the mining insect. Phenolic compounds are known to have anti-pathogen properties (Hagerman $\&$ Butler, 1989). Some phytophagous insects are capable of detoxifying quantitative chemical defenses. Others, in contrast, are physiologically adapted to tannins and other polyphenols, such as lignin (Panda \& Khush, 1995).

That adaptation can, in part, explain the sectioning of the vascular system by the mining larva found in $R$. riparia, at least during its later stages.

Another important observation revealed by the present structural analysis is the absence of new tissue formation in the mine of $R$. riparia. According to Mani (1964), in many mines the plant tissues remain relatively passive, while in others they react with some cell proliferation. That author observed that new tissue is formed in the proximity of vascular tissue, some distance away from the mining agent. He also pointed out that the neoplasic tissue is apparently the result of purely mechanical factors, and there is no specific relationship with the larvae of the leaf mine. In other cases, Mani (1964) noted that larvae first mine the midrib and then produce several lateral galleries. In later stages, the larva may return to the central mine and feed on regenerated tissues. Such tissues correspond structurally to the nutritive tissue found in galls. These facts corroborate what was postulated by Hering (1951), that mines are galls at an incipient stage of differentiation.

In many species of Asteraceae, there are cases where the insect forms a mine during part of its development, forming a gall at subsequent stages, as in those induced by Tephritidae in Cirsium arvense (Lalonde \& Shorthouse, 1984) and Solidago canadensis (Weis \& Abrahamson, 1986). In floral galls of Inula salicina, caused by Myopites blotii (Rohfristch \& Arnold-Rinehart, 1991), the larva mines only during the first and second larval stages, and feeds on the young cells of the tissue of the host plant. It stops mining upon reaching the vascular cambium. At that point, new tissues with large cells are formed. The latter are called nutritive tissue cells (which are similar to typical nutritive gall tissues). Although it was not possible to establish the cycle of the lepidopteran studied herein, it can be stated that it definitely behaves as a miner, at least in the stage available for this study.

In addition to their importance as occasional crop pests, mining insects are interesting organisms because of their peculiar feeding behavior - endophytophagy. This is not restricted to mining insects, since gall-forming insects are also endophytophagous. The difference between the two kinds of endophytophagy is based on the absence, in the mine, of growth and neoformation of tissues in the host plant, whereas in the galls there is atypical growth and formation of neoplasic tissues. Morphological and anatomical studies are therefore fundamental to a better understanding of these structures.

This study characterized the formation of a lepidopteronome in $R$. riparia, based upon the absence of neoformed tissues for the feeding of the larva. The mine reported in the present work can also be categorized as parenchymatic (most of the consumed tissues were parenchymatous), although the mining larva also consumes small sectors of the vascular system. In this gall, the epidermis remains intact, but forms a protective layer for the mining insect.

Acknowledgments - The authors thank Dr. Sérgio Vanin for identification of the mining larva reported and Dr. Mario Pinna for criticaly reading in this study. Research funding is provided by CNPq and Fapesp.

\section{REFERENCES}

BOLDT, P. E. \& WHITE, R. E., 1992, Life history and larval description of Exema elliptica Karren (Coleoptera: Chrysomelidae) on Baccharis halimifolia L. (Asteraceae) in Texas. Proc. Entomol. Soc. Wash., 94: 83-90.

CONNOR, E. F. \& TAVERNER, M. P., 1997, The evolution and adaptive significance of leaf-mining habit. Oikos, 79: 6-25.

CUTTER, E. G., 1978, Plant anatomy. Part I: cells and tissues. Edward Arnold, London, 315p.

FEENY, P., 1970, Seasonal changes in oak leaf tannins and nutrients as a cause of spring feeding by winter moth caterpillars. Ecology, 51: 565-581.

FEENY, P., 1976, Plant appearance and chemical defense. Rec. Adv. Phytochem, 10: 1-39. 
GOEDEN, R. D., HEADRICK, D. H. \& TERRINK, J. A., 1993, Life history and descriptions of immature stages of Tephritis arizonaensis Quisenberry (Diptera: Tephritidae) on Baccharis sarothroides Gray in Southern California. Proc. Entomol. Soc. Wash., 95: 210-222.

GOEDEN, R. D., HEADRICK, D. H. \& TERRINK, J. A., 1995, Life history and descriptions of immature stages of Urophora timberlakei Blanc and foote (Diptera: Tephritidae) on native Asteraceae in Southern California. Proc. Entomol. Soc. Wash., 97: 779-790.

HAGERMAN, A. E. \& BUTLER, R. G., 1989, Choosing appropriate methods and standards for assaying tannin. J. Chem. Ecol., 15: 1795-1810.

HERING, E. M., 1951, Biology of the leaf miners. Dr. W. Junk Gravenhage, Berlin, 420p.

HILL, D., 1987, Agricultural insect pests of temperate regions and their control. Cambridge University Press, Cambridge, 659p.

JOHANSEN, D. A., 1940, Plant microtechnique. McGrawHill Book Co. Inc., New York, 523p.

KRAUS, J. E. \& ARDUIN, M., 1997, Manual básico de métodos em morfologia vegetal. Editora Universidade Rural, Seropédica, 198p.

KRAUS, J. E., SOUSA, H. C., REZENDE, M. H., CASTRO, N. M., VECCHI, C. \& LUQUE, R., 1998, Astra blue and basic fuchsin double staining of plant materials. Biotech. \& Histochem., 73: 235-243.

LABANDEIRA, C. C., DILCHER, D. L., DAVIS, D. R. \& WAGNER, D. L., 1994, Ninety-seven million years of angiosperm-insect association: paleobiological insights into the meaning of coevolution. Proc. Nat. Acad. Sci., USA, 91: 12278-12282.

LALONDE, R. G. \& SHORTHOUSE, J. D., 1984, Developmental morphology of the gall of Urophora cardui (Diptera, Tephritidae) in the stems of Canada thistle (Cirsium arvense). Can. J. Bot., 62: 1372-1384.

LEWINSOHN, T. M., 1991, Insects in flower heads of Asteraceae Southheast Brazil: a case study on tropical species richness. In: P. W. Price, T. M. Lewinsohn, G. W. Fernandes \& W. W. Benson (eds.), Plant-animal interactions: evolutionary ecology in tropical and temperate regions. John Wiley \& Sons, Inc., New York, 525p.
LIPETZ, J., 1970, Wound healing in higher plants. Int. Rev Cytol., 27: 1-28.

MANI, M. S., 1964, Ecology of plant galls. Dr. W. Junk Publishers, The Hague, 434p.

McKEY, D., 1979, The distribution of secondary compounds within plants. In: G. A. Rosenthal \& D. H. Janzen (eds.), Herbivores: their interaction with secondary plant metabolites. Academic Press, London, 486p.

NEEDHAM, J. G., FROST, S. W. \& TOTHILL, D., 1928, Leaf-mining insects. The Williams \& Wilkens, Co., Baltimore, 351p.

PANDA, N. \& KHUSH, G. S., 1995, Host plant resistance to insects. Cab. International, Wallingford, 431p.

ROHFRISTCH, O. \& ARNOLD-RINEHART, H., 1991, Gall development and fine structure of the nutritive cells of Myopites blotii (Diptera, Tephritidae) on Inula salicina. Can. J. Bot., 69: 2232-2241.

SWAIN, T., 1979, Tannins and lignins. In: G. A. Rosenthal \& D. H. Janzen (eds.), Herbivores: their interaction with secondary plant metabolites. Academic Press, London, $486 \mathrm{p}$.

TEMPEL, A. S., 1981, Field studies of the relationships between herbivore damage and tannins concentration in bracken (Pteridium aquilinum Kuhn.). Oceologia, 51: 97 106.

WEIS, A. E. \& ABRAHAMSON, W. G., 1986, Evolution of host plant manipulation by gall makers: ecological and genetic factor in Solidago-Eurosta system. Am. Nat., 127: 681-695.

WEIS, A. E. \& BERENBAUM, M. R., 1989, Herbivorous insects and green plants. In: W. G. Abrahamson (ed.), Plant-animal interactions. McGraw Hill-Book Co., New York, 520p.

YEPSEN, R. B., 1976, Organic plant protection. Rodale Press Inc., Emmaus, 688p. 